Jurnal Manajemen Bisnis dan Manajemen Informatika

Journal homepage: www.stie-mandala.ac.id ISSN ...../ E-ISSN

\title{
PENGARUHKUALITAS PRODUK, HARGA, DANPROMOSI TERHADAP LOYALITAS MELALUI MINATPEMBELIANULANGSMARTPHONE XIAOMI DI JEMBER
}

Elfath Almas Alfafa ${ }^{a}$, Muhammad Firdaus ${ }^{b}$, Ahmad Sauqi ${ }^{\text {c }}$

${ }^{a}$ Mahasiswa STIE Mandala Jember,sadamalfafa@gmail.com

${ }^{b}$ Dosen STIE Mandala Jember,firdaus@stie-mandala.ac.id

${ }^{c}$ Dosen STIE Mandala Jember, sauqi@stie-mandala.ac.id

E-mail Penulis Korespondensi : sauqi@ stie-mandala.ac.id

I N F O A R T I K E L

Riwayat Artikel:

Dikirim 10 November

2020

Direvisi 15 November 2020

Diterima 21 November

2020

Keywords:

Product;

Promotion;

Smartphone.

Kata Kunci:

Produk;

Harga;

Promosi; Loyalitas;

Smartphone.

Loyalty;

\section{A B S T R A C T}

This study aims to analyze the effect of product quality, price, and the promotion of repurchase interest on the loyalty of Xiaomi Smartphone users in Jember District. Sampling using accidental sampling technique to 50 respondents. The results of the study show product quality, price, promotion have a significant effect on loyalty through the re-purchase interest of Price; $\quad$ Xiaomi Smartphone users in Sumbersari district.

Penelitian ini bertujuan untuk menganalisis pengaruh kualitas produk, harga, dan promosi minat pembelian ulang terhadap loyalitas pengguna Smartphone Xiaomi di Kecamatan Jember. Pengambilan sampel menggunakan teknik accidental Sampling kepada 50 responden. Hasil dari penelitian menunjukan kualitas produk, harga, promosi berpengaruh signifikan terhadap Loyalitas melalui minat pembelian ulang pengguna Smartphone Xiaomi di kecamatan Sumbersari.

\section{PENDAHULUAN}

Persainganyang semakin ketat menyebabkan perusahaan dituntut untuk menawarkan produk yang berkualitas,dan mampu mempunyai nilai lebih sehingga mempunyai perbedaan 
dengan pesaingnya. Kualitas produk menjadi salah satu pertimbangan konsumen sebelum memilih suatu produk, Menurut Kotler dan Keller (2009:143) penjualan telah menghantarkan kualitas ketika produk atau jasanya memenuhi atau melebihi ekspektasi pelanggan. Kualitas produk ditentukan oleh daya tahan, fungsi, dan manfaatnya, dengan adanya kualitas produk yang baik dan terpercaya maka konsumen akan semakin meningat jumlahnya. Penilaian terhadap kualitas suatu produk dapat dilakukan setelah konsumen membeli, menggunakan, atau mendapat rekomendasi dari orang terdekat tentang produk tersebut.

Salah satu produk Smartphone yang laris dipasaran Indonesia adalah Xiaomi yang merupakan produk asal china. Xiaomi sangat diminatidi Indonesia sebab memiliki harga yang terjangkau bagi orang Indonesia, dan spesifikasi produknya juga tidak kalah dengan brand lainnya yang mempunyai harga jauh lebih mahal dibandingkan Xiaomi. Presepsi yang ada dalam masyarakat melekat bahwa produk Xiaomi memiliki kualitas produk yang baik, sehingga masyarakat banyak memakai produk Xiaomi dibanding produk lain. Berdasarkan fenomena yang terjadi maka penelitian ini sangat penting dilaksanakan untuk meneliti tentang minat pembelian ulang terhadap smartphone.

Penelitian dengan judul pengaruh kualitas produk, harga, dan promosi terhadap loyalitas melalui minatpembelianulangsmartphone xiaomi di Jember bertujuan untuk mengetahui pengaruh secara langsung variabel independent ke variabel intervening, variabel indpendent ke variabel dependent dan variabel intervening ke variabel dependent. Berikutnya adalalah pengaruh secara tidak langsung variabel independent ke variabel dependent melaui variabel intervening.

\section{KAJIAN PUSTAKA}

Pemasaran dalam prakteknya merupakan suatu kegiatan pertukaranyang menguntungkan dengan target tertentu yang tujuannya memperoleh laba untuk perusahaan.Manajemen Pemasaran adalah merencanakan,pengarahan,dan pengawasan seluruh kegiatan pemasaran perusahaan ataupun bagian dipemasaran (Alma, 2004:6).Kualitas produk menurut Kotlerand Armstrong (Kotlerdan Armstrong,2013;151) adalah kemampuan sebuah produk dalam memperagakan fungsinya, halitu termasuk keseluruhan durabilitas, reliabilitas, ketepatan kemudahan pengoperasian dan reparasi produk juga atribut produklainnya. Menurut ahli Harga merupakan sejumlah uang yang dibebankan atas suatu barang atau jasa atau jumlah dari nilai uang yang ditukar oleh konsumen,yang memiliki manfaat untuk mendapatkan produk atau jasa 
(KotlerdanArmstrong, 2013:151).Promosi merupakan kegiatan yang dilakukan perusahaan dalam upaya mengkomunikasikan suatu produk kepada konsumen, sehingga produsen dapat mempengaruhi minat pembelian konsumen terhadap produk perusahaan. (Kotler dan Amstrong,2009:72). Sedangkan menurut Kotler, Bowen dan Makens (2014), minat belitimbul setelah adanya proses evaluasi alternatif. Kepuasan yang diperoleh seorang konsumen, dapat mendorong ia melakukan pembelian ulang (repeatpurchase), menjadi loyal terhadap produk tersebut ataupun loyal terhadap toko tempat dia membeli barang tersebut sehingga konsumen dapat menceritakan hal-hal yang baik kepada oranglain. Loyalitas pelanggan adalah komitmen pelanggan terhadap suatu merek, toko, atau pemasok, berdasarkan sikap sangat positif dan tercermin dalam pembelian ulang yang konsisten. Bagi perusahaan loyalitas pelanggan adalah hal yang penting dan merupakan bagian dari maju atau mundurnya perusahaan.(Tjiptono,2014:387). Loyalitas merupakan suatu kepercayaan suatu barang yang tidak bisa dibeli dengan uang, namun di dapatkan dari kepuasan seseorang yang membuat perilaku konsumtif meningkat pada merk barang yang sama. Pada bidang bisnis dan pemasaran, arti loyalitas adalah kemauan dari konsumen atau pelanggan untuk terus melakukan pembelian serta menggunakan produk dari perusahaan dalam jangka waktu yang lama.

\section{METODE PENELITIAN}

Populasi adalah wilayah generalisasi yang terdiri atas objek/subjek yang mempunyai kualitas dan karakteristik tertentu yang ditetapkan oleh peneliti untuk dipelajari dan kemudianditarik kesimpulannya (Sugiyono,2006:72). Populasi didalam penelitian ini adalah parapengguna Smartphone Xiaomi. Penelitian ini dilakukan dengan menyebar kuesioner pada Mahasiswa Universitas Jember, PoliteknikJember, STIE Mandala Jember, pengguna Xiaomi dan juga Outletdi Kecamatan Sumbersari Kabupaten Jember. Sampel adalah bagian dari jumlah dan karakteristik yang dimiliki oleh populasi tersebut. Bahwa populasi adalah boleh tidak terbatas suatu sample dari populasi. Cooper memberikan asumsi bahwa ukuran data jumlah absolut sampel adalah lebih penting dari pada ukuran jumlah aslinya terhadap populasi. Jumlah sampel 50 dirasa sudah memenuhi syarat suatu sampel yang sesungguhnya. Teknik sampling adalah teknik pengambilan sampel untuk menentukan sampel yang akan digunakan dalam penelitian. Besarnya jumlah sampel yang harus diambil dari populasi dalam suatu kegiatan penelitian sangat tergantung dari keadaan populasi itu sendiri. Teknik pengambilan Sampel yang akan digunakan dalam penelitian ini adalah Accidental samplingyaitu teknik penentuan sampel berdasarkan kebetulan,yaitu siapa saja yang secara 
kebetulan atau tidak sengaja bertemu dengan peneliti yang dapat digunakan sebagai sampel.

Bila dipandang orang yang kebetulan ditemui itu cocok sebagai sumber data maka orang tersebut dianggap sebagai. Metode pengumpulan data dengan kuisioner, observasi dan wawancara dan untuk sumber berupa data primer dan sekunder. Analisisdata yang digunakan dalam penelitian ini meliputi uji instrumen, analisis jalur dan uji t.

\section{ANALISIS DAN PEBAHASAN}

Uji validitas menganalisis dengan cara mengkorelasikan atau membandingkan masing-masing skor item dengan skor total dari data yang sudah diolah. Adapun syarat yang harus dipenuhi yaitu sebagai berikut : Jika Rhitung $\geq$ Rtabel $(0,284)$ dengan tingkat signifikansi $\leq 0,05$ maka item - item pertanyaan dari kuesioner adalah valid. Jika Rhitung $\leq$ Rtabel $(0,284)$ dengan tingkat sigfikansi $\geq 0,05$ maka item-item pertanyaan dari kuesioner adalah tidak valid. Rtabel $=0,284$ didapat melalui hasil yang sudah tertera di dalam Distribusi nilai Rtabel berdasarkan Rumus df $=\mathrm{N}-2$ dimana $\mathrm{N}=$ Banyaknya responden dengan signifikasi 5\% /0,05( $\alpha$ ) sebagai kepercayaan suatu data,maka didapat nilai Rtabel 50$2=48$ dengan sig 5\% jadi Nilai R tabe10,284.Hasil uji validitas menunjukkan nilai yang valid sesuai kriteria diatas, berikut hasilnya.

Uji Validitas InstrumenVariabel KualitasProduk(X1)

\begin{tabular}{|c|c|c|c|c|c|c|}
\hline No & Variabel & Indikator & R tabel & $\begin{array}{c}\mathrm{R} \\
\text { hitung }\end{array}$ & Sig & Keterangan \\
\hline 1 & Kualitas Produk (X1) & $\mathrm{X} 1.1$ & 0,284 & 0,538 & 0 & Valid \\
\hline 2 & Kualitas Produk (X1) & $\mathrm{X} 1.2$ & 0,284 & 0,411 & 0,003 & Valid \\
\hline 3 & Kualitas Produk (X1) & $\mathrm{X} 1.3$ & 0,284 & 0,771 & 0 & Valid \\
\hline 4 & Kualitas Produk (X1) & $\mathrm{X} 1.4$ & 0,284 & 0,700 & 0 & Valid \\
\hline 5 & Kualitas Produk (X1) & $\mathrm{X} 1.5$ & 0,284 & 0,588 & 0 & Valid \\
\hline
\end{tabular}

Uji Validitas InstrumenVariabel Harga (X2)

\begin{tabular}{|c|c|c|c|c|c|c|}
\hline No & Variabel & Indikator & $\begin{array}{c}\mathrm{R} \\
\text { tabel }\end{array}$ & $\begin{array}{c}\mathrm{R} \\
\text { hitung }\end{array}$ & Sig & Keterangan \\
\hline 1 & Harga(X2) & $\mathrm{X} 2.1$ & 0,284 & 0,455 & 0,001 & Valid \\
\hline 2 & Harga(X2) & $\mathrm{X} 2.2$ & 0,284 & 0,694 & 0 & Valid \\
\hline 3 & Harga(X2) & $\mathrm{X} 2.3$ & 0,284 & 0,635 & 0 & Valid \\
\hline 4 & Harga(X2) & $\mathrm{X} 2.4$ & 0,284 & 0,606 & 0 & Valid \\
\hline 5 & Harga(X2) & $\mathrm{X} 2.5$ & 0,284 & 0,672 & 0 & Valid \\
\hline
\end{tabular}

Uji Validitas InstrumenVariabel Promosi (X3)

\begin{tabular}{|c|c|c|c|c|c|c|}
\hline No & Variabel & Indikator & R tabel & $\begin{array}{c}\mathrm{R} \\
\text { hitung }\end{array}$ & Sig & Keterangan \\
\hline 1 & Promosi (X3) & X3.1 & 0,284 & 0,577 & 0 & Valid \\
\hline 2 & Promosi (X3) & X3.2 & 0,284 & 0,604 & 0 & Valid \\
\hline
\end{tabular}




\begin{tabular}{|c|c|c|c|c|c|c|}
\hline 3 & Promosi (X3) & X3.3 & 0,284 & 0,527 & 0 & Valid \\
\hline 4 & Promosi (X3) & X3.4 & 0,284 & 0,715 & 0 & Valid \\
\hline 5 & Promosi (X3) & X3.5 & 0,284 & 0,724 & 0 & Valid \\
\hline
\end{tabular}

Uji Validitas Instrumen Variabel Minat PembelianUlang(Y)

\begin{tabular}{|c|c|c|c|c|c|c|}
\hline No & Variabel & Indikator & $\begin{array}{c}\mathrm{R} \\
\text { tabel }\end{array}$ & $\begin{array}{c}\mathrm{R} \\
\text { hitung }\end{array}$ & Sig & Keterangan \\
\hline 1 & $\begin{array}{c}\text { Minat Pembelian } \\
\text { Ulang (Y) }\end{array}$ & Y1 & 0,284 & 0,837 & 0 & Valid \\
\hline 2 & $\begin{array}{c}\text { Minat Pembelian } \\
\text { Ulang (Y) }\end{array}$ & Y2 & 0,284 & 0,643 & 0 & Valid \\
\hline 4 & $\begin{array}{c}\text { Minat Pembelian } \\
\text { Ulang (Y) }\end{array}$ & Y3 & 0,284 & 0,790 & 0 & Valid \\
\hline 5 & $\begin{array}{c}\text { Minat Pembelian } \\
\text { Ulang (Y) }\end{array}$ & Y4 & 0,284 & 0,790 & 0 & Valid \\
\hline
\end{tabular}

Uji Validitas InstrumenVariabel Loyalitas (Z)

\begin{tabular}{|c|c|c|c|c|c|c|}
\hline No & Variabel & Indikator & $\begin{array}{c}\mathrm{R} \\
\text { tabel }\end{array}$ & $\begin{array}{c}\mathrm{R} \\
\text { hitung }\end{array}$ & Sig & Keterangan \\
\hline 1 & Loyalitas (Z) & $\mathrm{Z} 1$ & 0,284 & 0,740 & 0 & Valid \\
\hline 2 & Loyalitas (Z) & $\mathrm{Z} 2$ & 0,284 & 0,805 & 0 & Valid \\
\hline 3 & Loyalitas (Z) & $\mathrm{Z} 3$ & 0,284 & 0,687 & 0 & Valid \\
\hline 4 & Loyalitas (Z) & $\mathrm{Z4}$ & 0,284 & 0,703 & 0 & Valid \\
\hline 5 & Loyalitas (Z) & $\mathrm{Z} 5$ & 0,284 & 0,608 & 0 & Valid \\
\hline
\end{tabular}

Uji Reliabilitas adalah alat untuk mengukur suatu kuesioner yang merupakan indicator dari perubah atau konstruk. Suatu kuesioner dikatakan reliable atau handal jika jawaban seseorang terhadap pernyataan adalah konsisten atau stabil dari segi waktu ke waktu. Pengukuran yang memiliki reliabilitas yang tinggi adalah pengukuran yang dapatmenghasilkandatayangreliabel, batas minimum datadikatakan reliabel adalah 0,60. Croncbach Alpha (a) suatu variabel dikatakan reliable (handal) jika memiliki Croncbach Alpha > 0,90 maka reliabilitas dikatakan sempurna. Jika Croncbach Alpha 0,70- 0,90 maka reliabilitas dikatakan tinggi, jika Croncbach Alpha 0,50-0,70 maka reliabilitas moderat atau normal, dan jika Croncbach Alpha <0,50 maka reliabilitas rendah, jika Croncbach Alpha rendah kemungkinan satu atau beberapa item tidak reliabel (Ghozali,2009).

$$
\begin{array}{|c|c|}
\multicolumn{2}{|c|}{\text { ReliabilityStatistics }} \\
\text { Cronbach's Alpha } & \text { N ofItems } \\
.898 & 30
\end{array}
$$

Hasil dari variable penelitian kualitas produk, harga, promosi,minat pembelian ulang 
dan loyalitas dari penelitian akan dikatakan reliabel, jika hasil Croncbach Alpha lebih dari0,60, Berdasarkan Tabel 4.15 hasil uji reliabilitas dalam penelitian ini sebesar 0,898 sehingga reliabilitasnya dikatakan tinggi.

Analisis Jalur / Path Analysis adalah perkembangan dari analisis regresi. teknik Analisis Jalur bertujuan untuk menganalisis hubungan sebab akibat yang terjadi pada regresi berganda jika variabel bebasnya mempengaruhi variabel tergantung tidak hanya secara langsung tetapi juga secara tidak langsung. Dalam pengujian ini memiliki2 metode yaitu: metode 1 menghitung koefisien jalur Variabel bebas yaitu X1, X2 dan X3 terhadap Y. Metode 2 menghitung koefisien jalur Intervening yaitu variable X1, X2, X3 melalui Y terhadap Z. Pengujian ini dapat dilihat pada tabel model 1 sebagai berikut:

\section{Hasil Uji Analisis Jalur Model 1}

\begin{tabular}{|c|c|c|c|c|}
\hline \multicolumn{5}{|c|}{ ModelSummary } \\
\hline Model & $\mathrm{R}$ & R Square & AdjustedR Square & Std.Errorofthe Estimate \\
\hline 1 &, $582^{\mathrm{a}}$ & ,339 & ,296 & 2,892 \\
\hline
\end{tabular}

a. Predictors:(Constant), C,B,A

\begin{tabular}{|c|c|c|c|c|c|c|}
\hline \multicolumn{7}{|c|}{ Coefficients $^{\mathrm{a}}$} \\
\hline \multirow{2}{*}{\multicolumn{2}{|c|}{ Model }} & \multicolumn{2}{|c|}{ UnstandardizedCoefficients } & \multirow{3}{*}{$\begin{array}{c}\text { Standardized } \\
\text { Coefficients }\end{array}$} & \multirow{3}{*}{$\begin{array}{l}\mathrm{T} \\
-, 538 \\
\end{array}$} & \multirow{3}{*}{$\begin{array}{l}\text { Sig. } \\
, 593\end{array}$} \\
\hline & & $\mathrm{B}$ & Std.Error & & & \\
\hline \multirow[t]{4}{*}{1} & (Constant) & $-2,501$ & 4,645 & & & \\
\hline & A &, 532 &, 218 & 351 & 2,444 & ,018 \\
\hline & $\mathrm{B}$ &, 185 & ,221 &, 115 & ,836 & ,408 \\
\hline & $\mathrm{C}$ & ,383 &, 161 & ,299 & 2,376 &, 022 \\
\hline
\end{tabular}

a. DependentVariable, D

Mengacu pada output regresi model 1 pada bagian tabel "Coefficiens" dapat diketahui bahwa nilai signifikansi dari ketiga variabel bebasnya yaitu $X 1=0,018, X 2=$ 0,408, X3 = 0,022 yang mana variable X1 dan X3 lebih kecil dari 0,05 yang berarti variable $\mathrm{X} 1$ dan $\mathrm{X} 3$ berpengaruh signifikan terhadap $\mathrm{Y}$, namun pada variable $\mathrm{X} 2$ lebih besar dari 0,05 yang berarti tidak berpengaruh signifikan terhadap Y Besarnya nilai R Square yang terdapat pada tabel “ Model Summary" adalah sebesar 0,339, hal ini menunjukan bahwa sumbangan pengaruh X1,X2dan X3 terhadap Y adalah sebesar 33,9 $\%$, sementara sisanya $66,1 \%$ merupakan kontribusi dari variable variable lain yang tidak dimasukan dalam penelitian ini.

\section{Hasil Uji Anaisis Jalur Model 2}

\begin{tabular}{|l|r|r|r|r|}
\multicolumn{1}{|c|}{ ModelSummary } \\
\hline Model & \multicolumn{1}{|c|}{$\mathrm{R}$} & \multicolumn{1}{|c|}{$\begin{array}{c}\text { AdjustedR } \\
\text { R Square }\end{array}$} & $\begin{array}{c}\text { Std.Errorofthe } \\
\text { Estimate }\end{array}$ \\
\hline 1 &, $784^{\mathrm{a}}$ &, 615 &, 581 & 1,961 \\
\hline
\end{tabular}




\begin{tabular}{|c|c|c|c|c|c|c|}
\hline \multicolumn{7}{|c|}{ Coefficients $^{\mathrm{a}}$} \\
\hline & & \multicolumn{2}{|c|}{ UnstandardizedCoefficients } & \multirow{3}{*}{$\begin{array}{c}\begin{array}{c}\text { Standardized } \\
\text { Coefficients }\end{array} \\
\text { Beta } \\
\end{array}$} & \multirow{2}{*}{$\mathrm{T}$} & \multirow[b]{2}{*}{ Sig. } \\
\hline \multicolumn{2}{|c|}{ Model } & $\mathrm{B}$ & Std.Error & & & \\
\hline \multirow[t]{5}{*}{1} & (Constant) & $-1,240$ & 3,160 & &,- 392 & 697 \\
\hline & A &, 270 & 157 & ,203 & 1,720 & 092 \\
\hline & $\mathrm{B}$ &, 150 &, 151 &, 107 & ,994 & ,325 \\
\hline & C &, 188 &, 116 &, 167 & 1,628 &, 111 \\
\hline & $\mathrm{D}$ & ,459 &, 100 &, 522 & 4,587 & 000 \\
\hline
\end{tabular}

a.Dependent Variable: E

Mengacu pada output regresi model 2 pada bagian table "Coefficients" dapat diketahui bahwa nilai signifikansi dari keempat variable yaitu $X 1=0,092, X 2=$ 0,325,X3=0,111dan $Y=000$ yang mana variable $\mathrm{X} 1, \mathrm{X} 2$, dan $\mathrm{X} 3$ lebih besar dari 0,05 yang berarti tidak berpengaruh terhadapZ, namun variabel intervening Y lebih kecil dari 0,05 terhadap Z.Berarti variable $\mathrm{Y}$ berpengaruh signifikan terhadap variabel terikat $\mathrm{Z}$.

Besarnya nilai R Square yang terdapat pada table "ModelSummary" adalah sebesar 0,615 , hal ini menunjukan bahwa sumbangan pengaruh X1,X2, X3 dan $\mathrm{Y}$ terhadap $\mathrm{Z}$ adalah sebesar $61,5 \%$, sementara sisanya $38,5 \%$ merupakan kontribusi dari variable variable lain yang tidak dimasukan dalam penelitian ini. Secara detail berikut penjelasannya.

Analisis pengaruh $\mathrm{X} 1$ terhadap $\mathrm{Y}$ : dari analisis di atas diperoleh nilai signifikansi X1 sebesar 0,018 < 0,05. Sehingga dapat disimpulkan bahwa secara langsungterdapat pengaruh signifikan antara X1 terhadap $\mathrm{Y}$.

Analisis pengaruh $\mathrm{X} 2$ terhadap Y: dari analisis diperoleh nilai signifikansi X2 sebesar 0,408 > 0,05. Sehingga dapat disimpulkan bahwa secara langsungtidak terdapat pengaruh signifikan antara X2 terhadap $\mathrm{Y}$.

Analisis pengaruh $\mathrm{X} 3$ terhadap $\mathrm{Y}$ : dari analisis di atas diperoleh nilai signifikansi X3 sebesar 0,022 <0,05. Sehingga dapat disimpulkan bahwa secara langsungterdapat pengaruh signifikan antara X3 terhadap Y.

Analisis pengaruh $\mathrm{X} 1$ terhadap $\mathrm{Z}$ : dari analisis di atas diperoleh nilai signifikansi X1 sebesar 0,092 > 0,05. Sehingga dapat disimpulkan bahwa secara 
langsungtidak terdapat pengaruh signifikan antara X1 terhadap Z.

Analisis pengaruh X2 terhadap Z: dari analisis di atas diperoleh nilai signifikansi X2 sebesar 0,325>0,05. Sehingga dapat disimpulkan bahwa secara langsungtidak terdapat pengaruh signifikan antara X2 terhadap Z.

Analisis pengaruh X3 terhadap Z: dari analisis di atas diperoleh nilai signifikansi X3 sebesar 0,111 >0,05. Sehingga dapat disimpulkan bahwa secara langsung tidak terdapat pengaruh signifikan antara X3 terhadap Z.

Analisis pengaruh $\mathrm{Y}$ terhadap $\mathrm{Z}$ : dari analisis di atas diperoleh nilai signifikansi Y sebesar $0,000<0,05$. Sehingga dapat disimpulkan bahwa secara langsungterdapat pengaruh signifikan antara Y terhadap Z.

Analisis Pengaruh X1 melalui Y terhadap Z: diketahui pengaruh langsung yang diberikan X1 terhadap Z sebesar 0,203, sedangkan pengaruh tidak langsung $\mathrm{X} 1$ memalui $\mathrm{Y}$ terhadap $\mathrm{Z}$ adalah perkalian nilai beta $\mathrm{X} 1$ terhadap $\mathrm{Y}$ dengan nilai beta $\mathrm{Y}$ terhadap $\mathrm{Z}$ yaitu : $0,351 \times 0,522=0,183$. Maka pengaruh total yang diberikan $\mathrm{X} 1$ terhadap $\mathrm{Z}$ adalah pengaruh langsung ditambah dengan pengaruh tidak langsung yaitu : 0,203 $+0,183=0,386$. Berdasarkan hasil perhitungan di atas diketahui bahwa nilai pengaruh langsung sebesar 0,203 dan pengaruh tidak langsung sebesar0,183. Hasil ini menunjukan bahwa secara langsung X1 tanpa melalui $\mathrm{Y}$ mempunyai pengaruh lebih besar terhadap $\mathrm{Z}$ yaitu sebesar 0,203, daripada X1 melalui Y terhadap Z yaitu sebesar 0,183.

Analisis Pengaruh X2 melalui Y terhadap Z: diketahui pengaruh langsung yang diberikan $\mathrm{X} 2$ terhadap $\mathrm{Z}$ sebesar 0,107 , sedangkan pengaruh tidak langsung $\mathrm{X} 2$ memalui $\mathrm{Y}$ terhadap $\mathrm{Z}$ adalah perkalian nilai beta $\mathrm{X} 2$ terhadap $\mathrm{Y}$ dengan nilai beta $\mathrm{Y}$ terhadap $\mathrm{Z}$ yaitu : 0,115 x 0,522 = 0,060. Maka pengaruh total yang diberikan $\mathrm{X} 1$ terhadap $\mathrm{Z}$ adalah pengaruh langsung ditambah dengan pengaruh tidak langsung yaitu : $0,107+0,060=0,167$. Berdasarkan hasil perhitungan di atas diketahui bahwa nilai pengaruh langsung sebesar 0,107 dan pengaruh tidak langsung sebesar0,060. Hasil ini menunjukan bahwa secara langsung X2 tanpa melalui $\mathrm{Y}$ mempunyai pengaruh lebih besar terhadap $\mathrm{Z}$ yaitu sebesar 0,107 , daripada X2 melalui Y terhadap Z yaitu sebesar 0,060.

Analisis Pengaruh X3 melalui Y terhadap Z: diketahui pengaruh langsung yang diberikan $\mathrm{X} 3$ terhadap $\mathrm{Z}$ sebesar 0,167, sedangkan pengaruh tidak langsung $\mathrm{X} 3$ memalui $\mathrm{Y}$ terhadap $\mathrm{Z}$ adalah perkalian nilai beta $\mathrm{X} 3$ terhadap $\mathrm{Y}$ dengan 
nilai beta $Y$ terhadap $Z$ yaitu : $0,299 \times 0,522=0,156$. Maka pengaruh total yang diberikan $\mathrm{X} 3$ terhadap $\mathrm{Z}$ adalah pengaruh langsung ditambah dengan pengaruh tidak langsung yaitu : $0,167+0,156=0,323$. Berdasarkan hasil perhitungan di atas diketahui bahwa nilai pengaruh langsung sebesar 0,167 dan pengaruh tidak langsung sebesar0,156. Hasil ini menunjukan bahwa secara langsung X1 tanpa melalui $\mathrm{Y}$ mempunyai pengaruh lebih besar terhadap $\mathrm{Z}$ yaitu sebesar 0,163 , daripada X1 melalui Y terhadap Z yaitu sebesar 0,156 .

Uji t yaitu untuk menguji bagaimana pengaruh tiap variabel bebasnya secara sendiri - sendiri terhadap variabel terikatnya. Pengujian ini dilakukan dengan tingkat signifikansi $<5 \%$ atau dalam bentuk alpha 0,05 . Secara detailnya bisa dijabarkan sebagai berikut:

Perbandingan t hitung dengan $t$ tabel sebesar 2,444 > 2,012 sehingga dapat disimpulkan bahwa H1 diterima yang berarti bahwa kualitas produk berpengaruh terhadap minat pembelian ulang.

Perbandingan $\mathrm{t}$ hitung dengan $\mathrm{t}$ tabel sebesar 0,836 $<2,012$ sehingga dapat di simpulkan bahwa $\mathrm{H} 2$ ditolak yang berarti bahwa harga tidak berpengaruh terhadap minat pembelian ulang.

Perbandingan $\mathrm{t}$ hitung dengan $\mathrm{t}$ tabel sebesar 2,376>2,012 sehingga dapat di simpulkan bahwa H3 diterima yang berarti bahwa promosi berpengaruh terhadap minat pembelian ulang.

\section{PE M B A H A S A N}

Dalam interpretasi ini menjelaskan tentang sesingkat mungkin penjelasan dari data yang sudah diolah dan diteliti. Pengaruh 3 variabel kualitas produk (X1), harga (X2),promosi (X3) terhadap pembelian ulang (Y) dan juga intervening minat pembelian ulang (Y) pengaruhnya terhadap loyalitas (Z) dengan menggunakan 2 Model. Dalam penelitian ini objek adalah pengguna smartphone Xiaomi.

Dari pengambilan data menggunakan kuesioner dapat diketahui karakteristik pengguna smartphone Xiaomi adalah laki-laki 74\% dan pengguna lebih banyak adalah pelajar Mahasiswa 72\% diusia 21-30 tahun 54\% juga pendidikan terakhir responden kebanyakan adalah SMA 72\% sebagai hasil terbesar. Diketahui bahwa pengguna smartphone Xiaomi kebanyakan masih pelajar baik bangku sekolah maupun perguruan tinggi, hal ini memungkinkan bahwa smathphone Xiaomi bias membantu para pelajar dalam 
menyelesaikan suatu tugas.

Dari hasil Model 1 dapat diketahui nilai sig kualitas produk (X1) dengan nilai kepercayaan alpha sebesar $0,018<0,05$ dan $t$ hitung dengan $t$ tabel sebesar 2,444 2,012. sehingga dapat disimpulkan bahwa kualitas produk berpengaruh terhadap minat pembelian ulang. Artinya kualitas produk memiliki peran dalam mempengaruhi minat pembelian ulang dalam penggunaan produk smartphone Xiaomi. Namun dalam Model 2 antara kualitas produk (X1) terhadap loyalitas (Z) nilai kepercayaan alpha sebesar 0,092 > 0,05 dan thitung dengan ttabel sebesar 1,720 $<2,014$ sehingga dapat disimpulkan bahwa kualitas produk tidak berpengaruh terhadap loyalitas. Artinya kualitas produk tidak memiliki peran yang signifikan dalam mempengaruhi loyalitas. dalam penggunaan produk smartphone Xiaomi. Berdasarkan hasil perhitungan pengaruh Analisisj alur diketahui bahwa nilai pengaruh langsung yaitu kualitas produk (X1) terhadap loyalitas(Z) sebesar 0,203dan pengaruh tidak langsung yaitu kualitas produk (X1) melalui minat minat pembelian ulang (Y) terhadap loyalitas $(Z)$ sebesar 0,183. Hasil ini menunjukkan bahwa secara langsung X1 tanpa melalui Y mempunyai pengaruh lebih besar terhadap Z. Jadi responden merasa pengaruh kualitas produk lebih menjadikan loyalitas di bandingkan pengaruh melalui minat pembelian ulang smartphone Xiaomi.

Darihasil Model 1 dapat diketahui nilai sig Harga (X2) dengan nilai kepercayaan alpha sebesar 0,408 > 0,05 dan thitung dengan ttabel sebesar 0,836 $<2,012$ sehingga dapat disimpulkan bahwa harga tidak berpengaruh terhadapminatpembelian ulang. Artinya harga tidak memiliki peran dalam mempengaruhi minat pembelian ulang dalam penggunaan produk smartphone Xiaomi. Namun dalam Model 2 antara harga (X2) terhadap loyalitas(Z) nilai kepercayaan alpha sebesar 0,325>0,05 dan thitung dengan ttabel sebesar 0,994<2,014 sehingga dapat disimpulkan bahwa harga tidak berpengaruh terhadap loyalitas. Artinya harga tidak memiliki peran yang signifikan dalam mempengaruhiloyalitas. dalam penggunaan produk smartphone Xiaomi. Berdasarkan hasil perhitungan pengaruh Analisis jalur diketahui bahwa nilaipengaruh langsung yaitu Harga (X2) terhadap loyalitas (Z) sebesar 0,107 dan pengaruh tidak langsung yaitu harga(X2) melalui minat minat pembelian ulang (Y) terhadap loyalitas (Z) sebesar 0,060. Hasil ini menunjukkan bahwa secara langsung X2 tanpa melalui $\mathrm{Y}$ mempunyai pengaruh lebih besar terhadap Z. Jadi responden merasa pengaruh harga secara langsung lebih menjadikan loyalitas di bandingkan pengaruh melalui minat pembelian ulang smartphone Xiaomi.

Dari hasil hipotesis 3 dapat diketahui nilai sig Promosi (X3) dengan nilai kepercayaan alpha sebesar $0,022<0,05$ dan thitung dengan ttabel sebesar 2,376>2,012 
sehingga dapat disimpulkan bahwa Promosi berpengaruh terhadap minat pembelian ulang. Artinya Promosi memiliki peran dalam mempengaruhi minat pembelian ulang dalam penggunaan produk smartphone Xiaomi. Namun dalam Model 2 antara harga (X2) terhadap loyalitas $(Z)$ nilai kepercayaan alpha sebesar 0,111>0,05 dan thitung dengan ttabel sebesar $1,628<2,014$ sehingga dapat disimpulkan bahwa promosi tidak berpengaruh terhadap loyalitas. Artinya harga tidak memiliki peran yang signifikan dalam mempengaruhi loyalitas. dalam penggunaan produk smartphone Xiaomi Berdasarkan hasil perhitungan pengaruh Analisis jalur diketahui bahwa nilai pengaruh langsung yaitu Promosi (X3) terhadap loyalitas (Z) sebesar 0,167 dan pengaruh tidak langsung yaitu Promosi (X3) melalui minat minat pembelian ulang(Y) terhadapl oyalitas (Z) sebesar 0,156. Hasil ini menunjukkan bahwa secara langsung X1 tanpa melalui Y mempunyai pengaruh lebih besar terhadap Z. Jadi responden merasa pengaruh promosi lebih menjadikan loyalitas dibandingkan pengaruh melalui minat pembelian ulang smartphone Xiaomi.

\section{SIMPULAN}

Kualitas produk terbukti berpengaruh signifikan terhadap minat pembelian ulang. Artinya Smartphone Xiaomi memberikan produk yang berkualitas bagus, baik dari segi bahan baku dan produk yang tahan lama serta memiliki varian produk dan tipe, dengan hal demikian konsumen merasa spesifikasi yang dijanjikan memuaskan dan memberikan dampak minat pembeli ulang terhadap produk smartphone Xiaomi. Hasil ini menerima hipotesis awal yang menyatakan semakin tinggi Kualitas Produk akan semakin meningkatkan Minat Pembelian Ulang.

Harga terbukti berpengaruh signifikan terhadap minat pembelian ulang. Artinya harga smartphone Xiaomi yang bias dikatakan terjangkau dianggap pantas dan sesuai dengan kualitas dan manfaat yang dirasakan oleh konsumen, utamanya konsumen yang berprofesi sebagai Mahasiswa yang mempunyai kegiatan yang membutuhkan alat komunikasi yang berfasilitas banyak, sehingga dengan adanya harga yang pantasakan semakin meningkatkan minat pembelian ulang. Hasil ini menerima Hipotesis awal yang menyatakan Harga yang terjangkau akan semakin meningkatkan Minat Pembelian Ulang.

Promosi terbukti berpengaruh signifikan terhadapminat pembelian ulang.Artinyastrategi promosi yang dilakukan olehperusahaan Xiaomi melalui media cetak maupun elektronik,event-event,serta promo potonganharga sudah cukup baik dan mampu mempengaruhi konsumen untuk kembali menggunakanproduk dari iaomi.Hasilini menerimahipotesisyang menyatakan semakin tinggi Promosi akansemakin meningatkan 
Minat Pembelian Ulang.

Kualitas produk terbuktitidak berpengaruh signifikan terhadap loyalitas.Artinyakualitas produkyangdimilikioleh Xiaomiyaitu memilikimutu dan spesifikasi yang baik memang membuat responden tertarik untuk menggunakan smartphoneXiaomidalam penggunaan berikutnya,akan tetapi hal tersebut tidakmembuat responden smartphone Xiaomitidak terpengaruh dengan merek produk selain Xiaomi. Hasil ini menolak hipotesis yang menyatakan semakin tinggi kualitas produk maka akan semakin meningkatkan Loyalitas.

Harga terbukti tidak berpengaruh signifikan terhadap loyalitas. harga yangdiberikanoleh Xiaomi tidak mempengaruhires ponden,dengan kondisi demikian maka responden belum bias memilih smartphone Xiaomi sebagai pilihan utama dan masih bias berpindah kepada produk pesaing Xiaomi dengan harga yang menarik. Hasil ini menolak hipotesis yang menyatakan harga yang sesuai akan semakin meningkatkan Loyalitas.

Promosi terbukti tidak berpengaruh signifikan terhadap loyalitas. Artinya promosi yang dilakukan oleh Xiaomi yang dilakukan dimedia cetakdan elektronik serta promosi pada event-event tidak mengikat responden untuk tidak terpengaruhdengan produk-produk pesaing dari smartphone Xiaomi. Hasil ini menolak hipotesis awal yang menyatakan semakin tinggi promosimaka akan semakin meningkatkanloyalitas.

Minat pembelian ulang terbukti berpengaruh signifikan terhadap loyalitas. Artinya smartphone Xiaomi berhasil meningkatkan minat beli ulang pada konsumennya maka akan meningkatkan loyalitas konsumen untuk menggunakan produk Xiaomi. Hasil ini menerima hipotesis awal yang menyatakan semakin tinggi minat beli ulang maka akan semakin meningkatkan loyalitas.

\section{DAFTAR PUSTAKA}

Buchari Alma, , 2004, Manajemen Pemasaran dan Pemasaran Jasa, Edisi. Revisi, Bandung: Penerbit CV. Alfabeta

Ghozali,Imam.2009.“AplikasiAnalisisMultivariatedenganProgramSPSS“. Semarang: UNDIP. Ghozali

Kotler,PhilipdanKevinLaneKeller.2009. Manajemen Pemasaran. Jilid2, Edisi ke13, TerjemahanBob Sabran, MM. Jakarta: Erlangga

Rangkuti, Freddy. ((2009).Strategi Promosi yang Kreatif dan Analisis Kasus Integrated 
Marketing Communication. Jakarta:PT. Gramedia Pustaka Utama Kotler, Philip.(2002).

Marketing Management,Millenium Edition. New Jersey :Pearson Custom Publishing

Sugiyono.2006.Metode Penelitian Kuantitatif, Kualitatif dan R \&. D.Bandung:Alfabeta. Musfiroh

Tjiptono, Fandy. 2014. Pemasaran jasa. Prinsip, penerapan, dan penelitian.

Yogyakarta, Penerbit AndyYogyakarta 